\title{
PENGARUH PENAMBAHAN EKSTRAK ETANOL SABUT KELAPA MUDA (Cocos nucifera Linn) DALAM SARI JAGUNG MANIS (Zea mays var. saccharata) TERHADAP BAKTERI Staphylococus aureus DAN Shigella dysenteriae
}

\author{
[Addition Effect of Ethanol Extract of Jouvenile Coconut Husk (Cocos nucifera Linn) In \\ Sweet Corn Juice (Zea mays var. saccharata) Against Staphylococus aureus and Shigella \\ dysenteriae Bacteria]
}

\author{
Askhiatul Fitriah $^{1^{\star}}$, Khairuddin $^{1}$, Dwi Juli Puspitasari ${ }^{1}$ \\ 1) Jurusan Kimia, Fakultas MIPA, Universitas Tadulako, Palu \\ Jl. Soekarno Hatta Km.9, Kampus Bumi Tadulako Tondo Palu, Telp. 0451- 422611
}

*)Coresponding author: askhi27@gmail.com

Diterima 10 Oktober 2018, Disetujui 2 Desember 2018

\begin{abstract}
A research about addition effect of the ethanol extract of jouvenile coconut husk (cocos nucifera linn) in sweet corn juice (zea mays var. saccharata) against staphylococus aureus (Gram positive) and shigella dysenteriae (Gram negative) has been done. The objective of this research was to investigate the concentration additions effect of the ethanol extract of jouvenile coconut husk against growth of total bacterial colonies, and the lowest total bacterial colony growth of the ethanol extract of husk in sweet corn juice. The husk was macerated using ethanol as a solvent, then mixed with sweet corn juice with variation concentration of $1 \%, 2 \%, 3 \%, 4 \%$ and $5 \%$. Analysis of the total bacterial growth was determinated by TPC method. The results revealed that the lowest total bacterial colony growth was at concentration of $5 \%$ as much as $1,0 \times 10^{7} \mathrm{CFU} / \mathrm{mL}$ for bacteria Shigella dysenteriae and $1,6 \times 10^{7} \mathrm{CFU} / \mathrm{mL}$ for Staphylococus aureus.
\end{abstract}

Keywords: Zea mays var. saccharata, Cocos nucifera Linn, Antibacterial, total colonies

\begin{abstract}
ABSTRAK
Telah dilakukan penelitian tentang pengaruh penambahan ekstrak etanol sabut kelapa muda (cocos nucifera Linn) dalam sari jagung manis (zea mays var. saccharata) terhadap Staphylococcus aureus (gram positif) dan Shigella dysenteriae (gram negatif). Tujuan penelitian yaitu untuk mengetahui pengaruh penambahan konsentrasi ekstrak etanol sabut kelapa muda terhadap pertumbuhan koloni bakteri pada sari jagung manis, serta total pertumbuhan koloni bakteri terendah pada ekstrak etanol sabut kelapa muda dalam sari jagung manis. Metode maserasi digunakan dalam proses ekstraksi sabut kelapa muda dengan pelarut etanol, selanjutnya ekstrak sabut kelapa muda dicampurkan dengan sari jagung manis sesuai variasi konsentrasi $1 \%, 2 \%, 3 \%, 4 \%$ dan $5 \%$. Analisis total pertumbuhan bakteri ekstrak etanol sabut kelapa muda dalam sari jagung manis dilakukan dengan metode TPC. Hasil penelitian menunjukkan bahwa total pertumbuhan koloni bakteri terendah yaitu pada konsentrasi $5 \%$ untuk bakteri Shigella dysenteriae sebesar $1,0 \times 10^{7} \mathrm{CFU} / \mathrm{mL}$ dan Staphylococus aureus sebesar $1,6 \times 10^{7} \mathrm{CFU} / \mathrm{mL}$.
\end{abstract}

Kata kunci: Zea mays var. saccharata, Cocos nucifera Linn, antibakteri, total koloni 


\section{LATAR BELAKANG}

Tanaman kelapa (Cocos nucifera Linn) merupakan tanaman tropis dengan area dan tingkat produksinya yang cukup tinggi di Indonesia. Menurut Direktorat Jenderal Perkebunan (2014), di Indonesia luas areal tanam kelapa sebesar 3.570.932 Ha dengan penghasilan produksi sebanyak 2.968.578 ton. Berdasarkan Sumber data Badan Pusat Statistik Provinsi Sulawesi Tengah (2014), luas areal tanaman kelapa sebesar 213.881 Ha dan angka produksi sebanyak 190.568 ton.

Tanaman kelapa dikenal juga sebagai tanaman serba guna karena hampir seluruh bagian tanamannya dapat dimanfaatkan oleh manusia. Salah satunya adalah bagian buah kelapa yang banyak digunakan untuk pengobatan (Perry, 1980). Menurut AISKI (Asosiasi Industri Sabut Kelapa Indonesia) pada tahun 2014, asumsi setiap butir kelapa rata-rata mengandung serat kasar atau sabut kelapa sebanyak 35\%, maka jika potensi ini dihitung, Indonesia menghasilkan sabut kelapa sebanyak 4,5 juta Ton sampai dengan 5,25 juta Ton setiap tahun namun, Indonesia saat ini baru bisa mengolah serat kelapa sebesar $3,2 \%$ dari potensi bahan baku yang tersedia di Indonesia.

Sabut kelapa mengandung senyawa metabolit sekunder yang memiliki aktivitas antibakteri. Golongan senyawa metabolit sekunder adalah tanin, flavonoid, dan polifenol (Harborne, 1987). Marline (2004), melaporkan sabut kelapa dapat dimanfaatkan sebagai obat karena diduga mengandung tanin, yang merupakan senyawa kimia kompleks dan terdiri dari beberapa senyawa polifenol. Menurut Lisan (2015), kandungan tannin pada sabut kelapa muda sebesar 5,62\% sedangkan pada sabut kelapa tua sebesar $4,28 \%$.

Marline (2004) melaporkan bahwa ekstrak etanol sabut kelapa memiliki efek antidiare terhadap hewan uji tikus putih. Ekstrak etanol sabut kelapa (Cocos nucifera Linn) dilaporkan dapat menghambat pertumbuhan bakteri Escherichia coli dan Shigella dysenteriae (Dalimunthe dan Nainggolan, 2006). Wulandari (2017), menemukan bahwa ekstrak etanol $95 \%$ pada sabut kelapa muda, setengah tua, dan sabut kelapa tua memiliki daya hambat tertinggi terhadap bakteri uji gram negatif (E. coli) dan gram positif (S. aureus).

Beberapa senyawa antibakteri banyak ditambhakan dalam produk pangan, seperti sari jagung manis. Jagung manis (Zea mays var. saccharata) memiliki tingkat kelezatan tinggi dan juga mengandung nilai gizi yang tinggi bagi pertumbuhan manusia sehingga menjadi bahan pangan yang banyak diminati. Jagung jenis memiliki tektur yang lebih lunak dan kadar gula yang lebih tinggi daripada jagung biasa (Iskandar, 2006). Produk olahan jagung manis berupa sari jagung manis memiliki komposisi sifat kimia yang mirip dengan karakteristik susu 
sapi, susu kedelai, dan ASI. Tidak adanya kandungan kolesterol dalam sari jagung manis dapat menjadi alternatif lain untuk makanan bayi. Kenggulan lainnya adalah tidak memiliki gula laktosa sehingga sari jagung manis sangat sesuai dikonsumsi oleh penderita intoleransi laktosa (Satiarini, 2006).

Untuk daya tahan sari jagung manis, agar mutunya tidak berubah sari jagung manis harus diberi bahan pengawet alami. Salah satu bahan pengawet alami yang dapat digunakan adalah ekstrak etanol sabut kelapa. Salah satu sumber senyawa alaminya adalah tanin, yang mana sabut kelapa mengandung tanin berkisar 8-13\% (Francia et al., 1973). Tannin telah banyak dimanfaatkan dalam industri makanan dan minuman, seperti pada pengolahan minuman beralkohol (Arthur dan Rose, 1973).

Penelitian mengenai pengemasan sari jagung manis telah dilakukan oleh Setya (2010) dan hasil analisis TPC menunjukkan bahwa jumlah mikroba pada minuman sari jagung manis berkisar $5,8 \times 10^{4}$ sampai $3,2 \times 10^{5}$ koloni $/ g$ sampel. Selain itu, Rindengan et al. (2001) menggunakan sabut kelapa untuk mengawetkan nira kelapa dan dapat bertahan lebih dari 3 jam setelah penyadapan, serta menghasilkan warna kecokelatan sebagai warna alami produk palm wine (produk minuman beralkohol).

Hingga saat ini belum ada publikasi penelitian lebih lanjut mengenai penambahan senyawa alami untuk ananalisis jumlah koloni bakteri sari jagung manis. Berdasarkan pertimbangan di atas, perlu dilakukan penelitian tentang kajian aktivitas antibakteri ekstrak etanol sabut kelapa muda dalam sari jagung.

\section{METODE PENELITIAN}

\section{Bahan dan Peralatan}

Bahan dasar yang digunakan dalam penelitian ini adalah sabut kelapa muda (umur 4-6 bulan), dan jagung manis. Bakteri uji yang digunakan adalah biakan murni Staphylococus aureus sebagai bakteri gram positif dan Shigella dysenteriae sebagai bakteri gram negatif. Etanol 96\%, dragendroff, $\mathrm{NaCl} 10 \%, \mathrm{FeCl}_{3}$ $5 \%$, serbuk magnesium, $\mathrm{H}_{2} \mathrm{SO}_{4}$ Pekat, $\mathrm{HCl}$ pekat, $\mathrm{CH}_{3} \mathrm{COOH}$ glasial, Nutrient Agar (NA), Laktose Broth (LB), NaCl fisiologis 0,9\%, Ciprofloxacin, akuades, aluminium foil, plastik wrap, dan kertas saring whatman no.1.

Peralatan yang digunakan dalam penelitian ini adalah scan $\AA 500$, neraca analitik, blender, ayakan 60 mesh, oven, autoklaf, inkubator, laminar, rotary vakum evaporator, hot plate, botol semprot, spatula, pipet tetes, jangka sorong, jarum ose dan alat-alat gelas yang umumnya digunakan dalam Laboratorium biologi dan Laboratorium kimia.

\section{Prosedur Penelitian}

\section{Ekstraksi}

Ekstraksi dilakukan menggunakan metode maserasi. Sampel sabut kelapa kering ditimbang sebanyak 25 gram dan direndam dalam $500 \mathrm{~mL}$ pelarut etanol 
96\% selama 72 jam. Ekstrak disaring menggunakan kertas saring whatman No.1. Filtrat yang diperoleh diuapkan menggunakan rotary vakum evaporator hingga diperoleh cairan kental lalu dipekatkan dengan gan $\mathrm{N}_{2}$ sehingga diperoleh ekstrak sabut kelapa muda pekat.

\section{Uji Fitokimia Secara Kualitatif}

Uji fitokimia dilakukan untuk mengetahui kandungan metabolit sekunder pada ekstrak etanol sabut kelapa seperti tannin, flavonoid, alkaloid, polifenol dan steroid dengan menggunakan pereaksi yang spesifik.

\section{Pengolahan Sari Jagung Manis}

Tahap pertama dalam pembuatan sari jagung adalah jagung manis disortasi dan dibersihkan. Selanjutnya jagung manis direbus dalam air mendidih selama 5 menit, kemudian dipipil. Tahap berikutnya pipilan jagung manis sebanyak $50 \mathrm{~g}$ digiling menggunakan blender dengan penambahan $200 \mathrm{~mL}$ air panas $(1: 4 \mathrm{~b} / \mathrm{v})$. Selanjutnya sari jagung manis disaring sehingga diperoleh sari jagung manis murni. Kemudian pemasakan kembali serta pasteurisasi sari jagung manis selama 15 menit dengan suhu $80^{\circ} \mathrm{C}$. Setelah itu, ekstrak sabut kelapa muda dicampurkan dengan sari jagung manis sesuai konsentrasi $1 \%, 2 \%, 3 \%, 4 \%$ dan $5 \%$.

\section{Uji Aktivitas Antibakteri}

Pada pengujian zona hambat bakteri digunakan metode sumur difusi. Media
Nutrien Agar (NA) sebanyak $25 \mathrm{~mL}$ dicampur dengan $25 \mu \mathrm{L}$ suspensi bakteri uji sesuai perlakuan (Staphylococus aureus dan Shigella dysenteriae), dihomogenkan lalu dituang dalam cawan petri steril dan dibiarkan sampai memadat. Setelah itu dibuat 3 sumur atau lubang yang berdiameter $8 \mathrm{~mm}$ menggunakan alat pelubang. Setiap cawan pada lubang pertama berisi ekstrak sabut kelapa muda serta lubang atau sumur kedua dan ketiga berisi kontrol (untuk control negatif yaitu akuades dan untuk kontrol positif berupa Ciprofloxacin), setiap sumur diisi ekstrak dan kontrol sebanyak $50 \mu \mathrm{L}$, kemudian diinkubasi selama 24 pada suhu $37^{\circ} \mathrm{C}$, selanjutnya diamati dan diukur diameter zona hambat dengan jangka sorong.

\section{Analisis Total Pertumbuhan Bakteri (TPC)}

Pengenceran dilakukan dengan mengambil $1 \mathrm{~mL}$ ekstrak sabut kelapa muda dalam sari jagung manis dengan masing-masing konsentrasi $1 \%, 2 \%, 3 \%$, $4 \%$ dan $5 \%$. Kemudian $1 \mathrm{~mL}$ suspensi bakteri dimasukkan ke dalam masingmasing tabung reaksi berisi $8 \mathrm{~mL}$ media LB (tabung reaksi 1) lalu didiamkan pada suhu ruangan selama 60 menit. $\mathrm{NaCl}$ fisiologis $0,9 \%$ dimasukan ke dalam masing-masing tabung reaksi lain (tabung reaksi 2, 3, 4, dan 5) sebanyak $9 \mathrm{~mL}$. Selanjutnya suspensi media LB sebanyak $1 \mathrm{~mL}$ dimasukkan ke dalam (tabung reaksi 2) berisikan $9 \mathrm{~mL} \mathrm{NaCl}$ fisiologis 0,9\% (pengenceran $10^{-1}$ ). Suspensi pada pengenceran $10^{-1}$ sebanyak $1 \mathrm{~mL}$, 
dimasukkan ke dalam (tabung reaksi 3) berisikan $9 \mathrm{~mL} \mathrm{NaCl}$ fisiologis 0,9\% (pengenceran $10^{-2}$ ), dilakukan hingga pengenceran $10^{-5}$, lalu diambil $1 \mathrm{~mL}$ pada pengenceran $10^{-4}$ dan $10^{-5}$ dan dimasukkan ke dalam cawan petri kemudian ditambahkan 15-20 mL NA, cawan digoyang-goyangkan dengan gerakan memutar agar bakteri dan NA tercampur secara homogen, dibiarkan hingga memadat, lalu diinkubasi selama 4 hari pada suhu $37^{\circ} \mathrm{C}$, dan diamati setiap 12 jam serta dilakukan perhitungan dengan Scan $\AA 500$.

\section{HASIL DAN PEMBAHASAN}

Pada penelitian ini, pada ekstrak etanol sabut kelapa muda ditemukan adanya senyawa tannin, fenol dan flavonoid dan tidak ditemukan adanya steroid dan alkaloid.

Tabel 1. Hasil uji fitokimia

\begin{tabular}{cc}
\hline Golongan Senyawa & Hasil \\
\hline Tanin & + \\
Fenol & + \\
Flavonoid & + \\
Alkaloid & - \\
Steroid & - \\
\hline
\end{tabular}

Keterangan:

(+) : Terdeteksi adanya senyawa

$(-)$ : Tidak terdeteksi adanya senyawa

\section{Uji Aktivitas Antibakteri Ekstrak Etanol Sabut Kelapa Muda}

Uji aktivitas antibakteri ekstrak etanol sabut kelapa muda terhadap pertumbuhan bakteri gram positif (Staphylococus aureus) dan gram negatif (Shigella dysenteriae) dengan menggunakan metode sumur difusi, yang di tandai dengan terbentuknya zona bening di sekitar sumuran. Antibiotik Ciprofloxacin digunakan sebagai kontrol positif dan akuades sebagai kontrol negatif. Pengamatan terhadap diameter zona hambat dari ekstrak dengan pengukuran menggunakan jangka sorong. Hasil pengukuran zona hambat bakteri disajikan pada Tabel 2.

Tabel 2. Hasil pengukuran zona hambat bakteri Staphylococcus aureus dan Shigella dysenteriae pada ekstrak etanol sabut kelapa muda

\begin{tabular}{ccc}
\hline \multirow{2}{*}{ Sampel } & \multicolumn{2}{c}{$\begin{array}{c}\text { Diameter Rata-rata Zona } \\
\text { Hambat (mm) }\end{array}$} \\
\cline { 2 - 3 } & $\begin{array}{c}\text { Staphylococcus } \\
\text { aureus }\end{array}$ & $\begin{array}{c}\text { Shigella } \\
\text { dysenteriae }\end{array}$ \\
\hline Ekstrak & 18.37 & 19.81 \\
Etanol Sabut & Kelapa Muda & $\begin{array}{c}\text { Kontrol positif } \\
23.87\end{array}$ \\
Ciprofloxacin & $\begin{array}{c}\text { Kontrol negatif } \\
0\end{array}$ & 21.5 \\
Akuades & \begin{tabular}{c} 
Kond \\
\hline
\end{tabular}
\end{tabular}

Hasil yang diperoleh menunjukkan diameter zona hambat ekstrak etanol sabut kelapa muda lebih tinggi terhadap bakteri uji gram negatif (Shigelle dysenteriae) dibandingkan dengan bakteri uji gram positif (Staphylococcus aureus).

Berdasarkan kriterianya, daya hambat antibakteri ekstrak etanol sabut kelapa muda pada bakteri Staphylococcus aureus dan Shigella dysenteriae dengan zona hambat berturut-turut sebesar 18,37 mm dan 19,81 mm termasuk kategori kuat. Dengan demikian, diketahui bahwa konsentrasi ekstrak etanol sabut kelapa muda dapat menghambat pertumbuhan bakteri Staphylococcus aureus dan Shigella dysenteriae. Sehingga ekstrak 
etanol sabut kelapa muda dapat digunakan sebagai bahan (senyawa alami) pada penelitian tahap lanjut yaitu analisis pertumbuhan jumlah koloni bakteri campuran ekstrak sabut kelapa muda dalam sari jagung manis.

\section{Pertumbuhan Bakteri pada Ekstrak Etanol Sabut Kelapa Muda dalam Sari Jagung Manis}

Analisis total pertumbuhan bakteri dengan prinsip suspensi bakteri dihomogenkan dengan ekstrak pada media LB, kemudian ditumbuhkan pada media NA merupakan salah satu media yang umum digunakan dalam pengujian bakteri. Pengenceran dilakukan secara bertingkat. Menurut Fardiaz (1992), koloni yang bergabung menjadi satu merupakan satu kumpulan koloni yang besar di mana jumlah koloninya diragukan sehingga dihitung sebagai satu koloni, dan satu deretan rantai koloni yang terlihat sebagai suatu garis tebal dihitung sebagai satu koloni. Adapun hasil data total pertumbuhan bakteri dapat dilihat pada Tabel 3.

Table 3. Hasil Analisis Pertumbuhan Bakteri Staphylococcus aureus dan Shigella dysenteriae pada penggunaan ekstrak etanol sabut kelapa muda dalam sari jagung manis.

\begin{tabular}{ccc}
\hline \multirow{2}{*}{$\begin{array}{c}\text { Konsentrasi } \\
(\%)\end{array}$} & $\begin{array}{c}\text { Total Pertumbuhan Bakteri } \\
\text { (CFU/mL) }\end{array}$ \\
\cline { 2 - 3 } & $\begin{array}{c}\text { Staphylococcus } \\
\text { aureus }\end{array}$ & $\begin{array}{c}\text { Shigella } \\
\text { dysenteriae }\end{array}$ \\
\hline $1 \%$ & $2,5 \times 10^{\prime}$ & $2,0 \times 10^{\prime}$ \\
$2 \%$ & $2,3 \times 10^{7}$ & $1,8 \times 10^{7}$ \\
$3 \%$ & $2,0 \times 10^{7}$ & $1,5 \times 10^{7}$ \\
$4 \%$ & $1,8 \times 10^{7}$ & $1,3 \times 10^{7}$ \\
$5 \%$ & $1,6 \times 10^{7}$ & $1,0 \times 10^{7}$ \\
\hline
\end{tabular}

Hasil pertumbuhan total koloni bakteri terendah ekstrak sabut kelapa muda dalam sari jagung manis yaitu pada konsentrasi 5\% untuk bakteri Staphylococus aureus (gram positif) sebesar $1,6 \times 10^{7} \mathrm{CFU} / \mathrm{mL}$ dan pada bakteri Shigella dysenteriae (gram negatif) sebesar $1,0 \times 10^{7} \mathrm{CFU} / \mathrm{mL}$. Hasil ini sesuai dengan hasil uji diameter daya hambat yang menunjukkan ekstrak etanol sabut kelapa muda memiliki daya hambat terbesar pada bakteri Shigella dysenteriae dibandingkan bakteri Staphylococus aureus. Hasil pertumbuhan total koloni bakteri ekstrak sabut kelapa muda dalam sari jagung manis menunjukkan semakin tinggi konsentrasi ekstrak maka semakin rendah total koloni bakteri. Hal ini sesuai dengan literatur Widyasanti et al., (2016), menyatakan bahwa semakin tinggi diameter daya hambat ekstrak maka semakin rendah total pertumbuhan bakteri.

Uji total pertumbuhan bakteri yang dilakukan pada ekstrak etanol sabut kepala muda dalam sari jagung manis menggunakan metode TPC, dilakukan pengamatan selama 4 hari dan dihitungi setiap 12 jam. Hal tersebut dapat dilihat pada grafik total pertumbuhan bakteri Staphylococus. aureus dan Shigella dysenteriae ekstrak etanol sabut kelapa muda dalam sari jagung manis (Gambar 1 dan Gambar 2). 


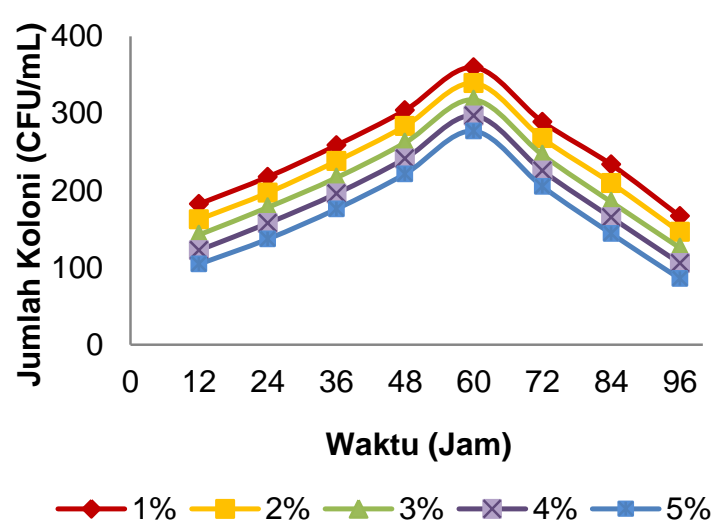

Gambar 1 Pertumbuhan bakteri Staphylococus aureus pada berbagai konenstrasi ekstrak etanol sabut kelapa muda dalam sari jagung manis

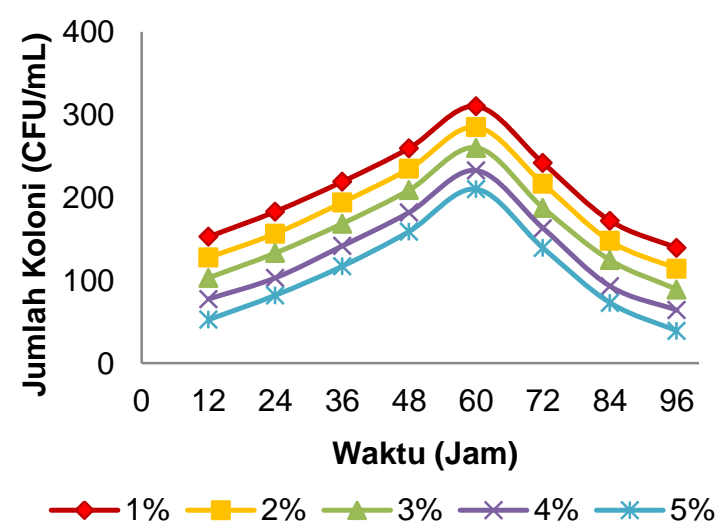

Gambar 2 Pertumbuhan bakteri Shigella dysenteriae pada berbagai konsentrasi ekstrak etanol sabut kelapa muda dalam sari jagung manis

Berdasar hasil yang diperoleh (Gambar 1 dan 2), diketahui bahwa pada penyimpanan pada hari pertama (12-24 jam) merupakan fase adaptasi bagi bakteri, selanjutnya pada hari ke dua (3648 jam) dan hari ke tiga (60-72 jam) merupakan fase eksponensial yang mana pertumbuhan bakteri terus berlangsung dan meningkat dengan pesat sehingga nilai TPC terus meningkat untuk kemudian turun setelah memasuki fase kematian di hari ke empat (84-96 jam).
Berdasarkan uji statistik untuk analisis sidik ragam ANOVA bakteri Staphylococus aureus dan Shigella dysenteriae dengan nilai $(\alpha=0,05)$ menunjukkan bahwa konsentrasi berpengaruh signifikan terhadap waktu namun interaksi antara konsentrasi dan waktu tidak berpangaruh signifikan.

\section{KESIMPULAN}

Berdasarkan hasil penelitian yang telah dilakukan dapat disimpulkan bahwa konsentrasi ekstrak sabut kelapa muda sangat berpengaruh terhadap total pertumbuhan koloni bakteri sari jagung manis. Adapun total pertumbuhan bakteri terendah yaitu pada konsentrasi 5\% untuk bakteri gram negatif (Shigella dysenteriae) sebesar $1.0 \times 10^{7} \mathrm{CFU} / \mathrm{mL}$ dan untuk bakteri gram positif (Staphylococus aureus) sebesar $1,6 \times 10^{7} \mathrm{CFU} / \mathrm{mL}$.

\section{DAFTAR PUSTAKA}

AISKI. 2014. Pemanfaatan produk unggulan sabut kelapa dan akses pemasaran bagi pengembangan usaha KUMKM. TTG Biltar: Bahan Presentasi Efli Ramli.

Arthur dan E. Rose. 1973. The condensed chemical dictionary, seventh edition. Taiwan. 1044p.

Badan Pusat Statistik. 2014. Luas areal dan produksi tanaman kelapa di Sulawesi Tengah. Palu: Data Badan Pusat Statistik Sulawesi Tengah.

Dalimunthe A., dan Nainggolan M. 2006. Pengujian ekstrak etanol sabut kelapa (Cocos nucifera Linn) terhadap bakteri Escherichia coli dan Shigella dysenteriae. Jurnal komunikasi penelitian. 18 (3).

Direktorat Jenderal Perkebunan. 2014. Luas areal dan produksi kelapa 
Indonesia. Jakarta: Data Direktorat Jenderal Perkebunan.

Fardiaz, S. 1992. Mikrobiologi Pangan 1. Bogor: PAU Pangan dan Gizi IPB Bogor dan Jakarta: Gramedia Pustaka Utama.

Francia, T.C., E.U. Escolano and J.A. Semana. 1973. Proximate chemical composition of the various parts of the coconut palm. Philippine: The Philippine Lumberman. XIX (7).

Harborne, J.B 1987. Metode fitokimia penuntun cara modern menganalisa tumbuhan edisi ke-2. Bandung: Penerbit ITB Halaman: 5, 234.

Iskandar, D. 2006. Pengaruh dosis pupun $\mathrm{N}$, $\mathrm{P}$, dan $\mathrm{K}$ terhadap produksi tanaman jagung manis di lahan kering. Balai Penelitian Pertanian dan Teknologi: Jurnal Saint dan Teknologi, 2 : 1-2.

Lisan, R.F. 2015. Penentuan jenis tanin secara kualitatif dan penetapan kadar tannin dari serabut kelapa (Coccos nucifera L) secara permanganometri. Jurnal IImiah Mahasiswa Universitas Surabaya, 4 (1).

Marline, N. 2004. Pemeriksaan senyawa kimia sabut kelapa (Coccos nucifera Linn) dan uji efek antidiare terhadap tikus putih secara in vitro.
Media Farmasi An Indonesia Pharmaceutical Journal, 13(1).

Rindengan B. S, Karouw, dan J. Mawikere. 2001. Sabut kelapa sebagai pengawet alami nira kelapa. Buletin Palm. 27: 21-26.

Satiarini, B. 2006. Kajian produksi dan profitabilitas pembuatan susu jagung. [Skripsi]. Bogor: Departemen Teknologi Industri Pertanian Fakultas Pertanian IPB.

Setya, I. A. 2010. Pengemasan dan penyimpanan minuman sari jagung. [Skripsi]. Bogor: Departemen Teknologi Industri Pertanian Fakultas Pertanian IPB.

Widyasanti A, Mega Priantiwi A, dan Rohdiana D. 2016. Aktivitas antibakteri Bacillus cereus dan Shigella dysenteriae ekstrak teh putih dalam variasi jenis pelarut. Jurnal Penelitian Teh dan Kina, (19) 1: 41-56

Wulandari A. 2017. Aktivitas antibakteri ekstrak etanol sabut kelapa (Cococ nucifera Linn) pada berbagai tingkat ketuaan. [Skripsi]. Palu: Program Studi S1 Kimia, Jurusan Kimia Fakultas Matematika dan IImu Pengetahuan Alam Universitas Tadulako. 